CULTURE (AND RELIGION) IN CONSTITUTIONAL ADJUDICATION

ISSN 1727-3781

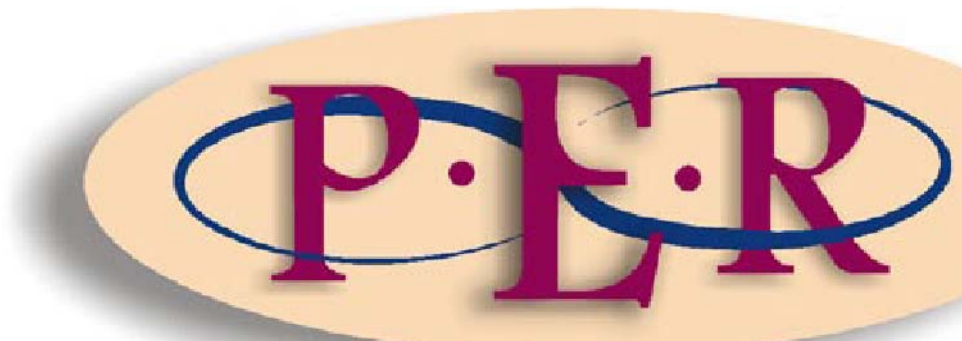

2003 VOLUME 6 No 1 


\title{
CULTURE (AND RELIGION) IN CONSTITUTIONAL ADJUDICATION
}

\author{
Prof Christa Rautenbach \\ Dr Fanie Jansen van Rensburg** \\ Prof Gerrit Pienaar***
}

\section{$1 \quad$ Introduction}

The 1996 Constitution $^{1}$ and its predecessor ${ }^{2}$ were responsible for revolutionary changes in the constitutional history of South Africa. Probably one of the most important changes is the replacement of parliamentary sovereignty with constitutional supremacy. Coupled with that was the enactment of an entrenched Bill of Rights ${ }^{4}$ and the establishment of a constitutional court with final jurisdiction over constitutional matters. ${ }^{5}$ The judiciary and, especially the members of the constitutional court, play a very important role within this dispensation.

The task of the judiciary has been described as follows:

It will be the task of the judiciary - and especially the members of the constitutional court - to vindicate the fundamental rights of those litigants who come before them. It will be their task to interpret the provisions, give them meaning and

* Revised paper delivered at the 5th Colloquium on Constitution and Law, Johannesburg 16 November 2002. The paper forms part of a project of the faculty of law, Potchefstroom University for CHE in corroboration with the Konrad-Adenauer-Stiftung on Politics, Socio-Economic Issues and Culture in Constitutional Adjudication. We would like to thank Prof JD van der Vyver for comments that he made on an earlier draft of this article.

** B luris LLB LLM LLD. Associate Professor, faculty of law, Potchefstroom University for CHE.

*** D.Phil. Senior Researcher (Social Anthropology), Focus Area for Sustainable Social Development, Potchefstroom University.

**** B lur et Comm LLB LLD. Professor, faculty of law, Potchefstroom University for CHE.

1 Constitution of the Republic of South Africa 108 of 1996 (hereinafter referred to as the 1996 Constitution).

2 The Constitution of the Republic of South Africa 200 of 1993 (hereinafter referred to as the 1993 Constitution).

3 Section 4 of the 1993 Constitution and section 2 of the 1996 Constitution.

4 Contained in chapter 3 of the 1993 Constitution and chapter 2 of the 1996 Constitution.

5 Section 98(1) of the 1993 Constitution and sections 166 and 167 of the 1996 Constitution.

6 Heath and Blomkamp (eds) "Foreword" in 19941 BCLR vi. 
context, and to set the bounds of constitutionally permissible limitations on them. This will require adapting to and developing new ways of thinking. Judicial officers and legal practitioners will, in a sense, have to make a new start. ... In this journey, some will of necessity be in the advance guard, setting up the guideposts for those to follow.

In order to contribute to the setting up of guideposts for South African courts the faculty of law of the Potchefstroom University for Christian Higher Education in corroboration with the Konrad-Adenauer-Stifttung embarked on a study on Politics, Socio-Economic Issues and Culture in Constitutional Adjudication. The aim of the project is twofold. The first aim is to analyse the influence of political, socio-economic and cultural considerations on the constitutional court's interpretation and application of the Bill of Rights. The second aim is to develop practical guidelines (based on the findings during the analysing process) for South African courts confronted with issues of a political, socio-economic and cultural nature. This article is concerned with initiating discussions of the decisions of the constitutional court with regard to cultural and religious rights.

However, before we can explore the role of political, socio-economic and cultural (and religious) rights in the decisions of the constitutional court it is important to discuss a few preliminary issues.

Firstly, the meaning of culture and religion within the South African context warrants some explanation. Secondly, some comments regarding constitutional protection of culturally and religiously based rights will be made. This may well be a daunting task, not only in view of the seemingly abysmal gap between the applicable constitutional values enshrined in the 1996 Constitution and cultural and religious values that, in some instances over

7 Own emphasis. The purpose of the project on Politics, Socio-Economic Issues and Culture in Constitutional Adjudication will be to develop practical guidelines for South African courts 
centuries, brought about customs and practices within "traditional" communities which seemingly, infringe on some of these constitutional values and rights.

\section{Meaning of culture and religion and the 1996 Constitution}

Various sections in the 1996 Constitution make use of terms such as "culture", "tradition" and "religion" to refer to the cultural diversity of South Africa. However, the 1996 Constitution does not define these terms and it is necessary to determine what culture, tradition and religion in the 1996 Constitution entails for purposes of this study.

The 1996 Constitution uses the term "culture" in three distinct ways. Firstly, culture is used as a specific tradition based on ethics. In this sense it is used to describe the development or improvement of a situation. For example, it is one of the functions of the South African Human Rights Commission to promote a "culture of human rights." The constitutional court has also used the term "culture" in a similar context, for example:

- Islamic Unity Convention v Independent Broadcasting Authority: "[A] society based on a constitutionally protected culture of openness and democracy and universal human rights for South Africans."

- Khumalo v Holomisa: "[T]he development of a democratic culture."

- $\quad S v$ Walters: "[P]romoting a culture of respect for human life and dignity."

- $\quad S v$ Williams: ${ }^{13}$ Courts have a role to play in the promotion and development of a new culture "founded on the recognition of human nights."

confronted with political, socio-economic and cultural issues.

8 Sections 9, 30, 31, 181, 184-186, 235 as well as schedules 4 and 5 refer to culture, cultural life, cultural community and cultural heritage. Sections 9, 15-16, 31 and 37 refer to religion, conscience, thought, belief and opinion and sections 15, 143, 211-212, 219 as well as schedules 4 and 5 refer to tradition or traditional leaders.

9 Own emphasis. See sections 184 and 234 of the 1996 Constitution.

1020024 SA 294 (CC) par [27]. Own emphasis.

1120025 SA 401 (CC) par [24]. Own emphasis.

1220024 SA 613 (CC) [6]. Own emphasis. 
The values of human rights, as explicated in the Constitution (democracy, openness, respect for human life and dignity) are contrasted to values in "other" systems, implying a preference for the former and the need to change the latter to conform to the ideals of the Constitution. From a viewpoint of cultural relativism this apparent evaluation of some elements of a cultural system by using another cultural system as context is very problematic and should be (re-)considered with some scepticism. Oversimplification of this problem can have dire effects on a global approach to human rights. In practical terms, we also know that the promotion of the values of human rights, which has become a strong universal trend, also has its own cultural (albeit diverse), and mostly 14

"Western" background. Although it should be possible to have universal agreement on fundamental human rights, the real possibility of Western domination should also here be borne in mind.

Secondly, the term "culture" is used as a collective term for aesthetical expression. In this sense, culture means, inter alia, literature, theatre, music and sculpture. The Culture Promotion Act ${ }^{16}$ serves as an example of legislation dealing with culture in such a sense. The use of culture to signify performing and plastic arts is not consistent with the first and broader use of the term and is also a very limited way of seeing culture which actually is mostly viewed by social scientists as the product of all human activity.

Thirdly, the term "culture" is used as a modality that identifies and binds a specific group of people. Culture is then understood as a determining source of identity - it draws distinctions between people on grounds of a

1319953 SA 632 (CC) par [8].

14 Gaete "The West, its Other and human rights" in Skelton \& Allen (eds) Culture and Global Change (Routledge London \& New York 1999) 193-200.

15 Currie "Minority Rights: Education, Culture, and Language" in Chaskalson et al(eds)Constitutional Law of South Africa (Juta Kenwyn 1999) 35.19 prescribes culture "the practice of intellectual and artistic activity and the works that result from that activity". See also Murray et al (eds) The Oxford English Dictionary (Vol II) (Clarendon Press Oxford 1978) 1247 at "culture".

1635 of 1983.

17 Keesing "Cultural Anthropology; a Contemporary perspective" (1998 Harcourt Brace College Publishers Fort Worth) $14-16$

18 Currie Minority Rights 35.19 points out that culture can be "a particular way of life of an identifiable group of people." 
number of characteristics such as language, religion, beliefs and traditions. In the Minister of Defence $v$ Potsane; Legal Soldier (Pty) Ltd v Minister of Defence ${ }^{20}$ the constitutional court afforded a similar meaning to the concept of culture. In this case the constitutionality of military prosecutions in terms of the Military Discipline Supplementary Measures Act ${ }^{21}$ of common law and statutory crimes was challenged because of its inconsistency with the provisions of section 179 of the 1996 Constitution. $^{22}$ In order to interpret section 179 Kriegler $\mathrm{J}$ gave a wide meaning to culture by recognising the fact that military service, military life and military discipline is a subculture of its own. It is a separate system with its own unique rules, offences and punishments. ${ }^{23}$ It is clear that, in terms of the above, a group of people with certain characteristics may be classified as a group with a culture of its own.

Bennet's $^{24}$ discussion of the meaning of culture seems to capture some of the possible important meanings of the concept, namely:

In common parlance ... 'culture' implies high intellectual or artistic endeavour. ... But 'culture' may also denote a people's entire store of knowledge and artefacts, especially the languages, systems of belief, and laws, that give social groups their unique characters. This meaning would encompass a right to customary law, for customary law is peculiarly African, in contrast with the law of a European origin.

It is clear that the term "culture" is wide enough to include other concepts such as religion and tradition. This inference is supported by the dictionary

19 Sections 30 and 31 of the 1996 Constitution do not refer to culture in general but to "cultural life" and "their culture". According to Currie Minority Rights 35.19 this indicates that culture in this context refers to a number of synonymous terms such as tradition, customs, civilisation, race, nation and folkways.

20200011 BCLR 1137 (CC).

$21 \quad 16$ of 1999.

22 Section 179 creates the office of the National Director of Public Prosecutions and governs its powers and functions.

23 See par 30. 
definitions of religion, ${ }^{25}$ conscience, ${ }^{26}$ thought, ${ }^{27}$ belief ${ }^{28}$ and opinion. ${ }^{29}$ Religion is normally associated with the existence of a God or gods to whom some form of worship and obedience is due. ${ }^{30}$ Other definitions require only a devotion to some or other principle and the exercise or practice of rites and observances. Conscience includes systems of belief which are not centred on a deity. It envisages a moral judgement and can include agnosticism and atheism. Thought, belief and opinion, on the other hand, do not envisage a moral element - it simply denotes the application of human reason. Tradition, on the other hand, means the transmission of statements, beliefs, rules, habits, principles, practices and customs from one generation to another.

The above depictions of culture, albeit with some serious limitations, when referring to a "way of life"; or a "source of identity"; also, language, religion, beliefs and traditions; and also some of Bennett's descriptions, have valuable points of departure for understanding culture as a human resource.

However, depictions of culture as "belonging" to "an identifiable group of people"; and that different aspects of life, such as languages, systems of belief, and laws "give social groups their unique characters" or the "characteristics" (i.e. language, religion and traditions) that distinguish one cultural group from another", can be very problematic for modern social scientists because:

- Although variation or diversity is common among humans, the boundaries between so-called cultures cannot be indicated in a scientific or precise manner.

24 Bennet Human Rights and African Customary Law 23-24.

25 Religion is the belief in a superhuman controlling power, especially in a personal God or gods entitled to obedience and worship.

26 Conscience is a sense of right and wrong.

27 Thought is the process of power of thinking.

28 Belief is a firm opinion in things.

29 Opinion is what one thinks about something.

30 Wyld (ed) The Universal Dictionary of the English Language (George Routledge \& Sons London 1946) 992.

31 Murray The Oxford English Dictionary (Vol VIII) 410 at "religion".

32 Murray The Oxford English Dictionary ( $\mathrm{Vol} \mathrm{XI)} 226$ at "tradition" and Wyld The Universal Dictionary of the English Language 1278. 
- Interaction (and not isolation) is very much part of human life and therefore cultural resources are shared, exchanged, adapted and controlled by intelligent actors in situations that have to be evaluated and negotiated by them from day to day.

- Human categories (such as ethnic groups, nations, status classes and age categories) use a myriad of complex resources. These resources are used (or sometimes not used) and negotiated between humans in everyday social interaction.

- It is dangerous to categorise people in terms of their cultural diversity as if this diversity is imposed on them and is static in nature.

- $\quad$ People do use cultural resources in an imaginative way to draw boundaries and give "content" to different identities such as: South African, Xhosa, gangster, Communist, business woman, Rastafarian, Muslim, poor, educated, right-winger, coffee drinker or share holder.

In spite of these shortcomings in the definition of culture, the concept "culture" will be used in this article as a collective term describing the human condition, but with diverse expressions and practices (i.e. different languages, religions and traditions) that are used by actors to distinguish one cultural or religious group from another.

\section{Constitutional protection of cultural and religiously based rights}

Various constitutional provisions clearly refer to the cultural "diversity" of the South African population. For example:

- The preamble to the Constitution refers to the diversity of South Africa.

33 Thornton "Culture: a Contemporary Definition" in Spiegel \& Boonzaier (eds) South African Keywords: the Uses and Abuses of Poltical Concepts (David Philip Cape Town 1988) 17 28. Eriksen "Common Denominators" (Berg Oxford \& New York 1998) 22-28. 
- Various provisions refer to traditional communities adhering to a system (in fact, often systems) of customary law.

- $\quad$ Schedules 4 and 5 refer to cultural matters (probably the arts) that resort under the functional areas of national and provincial government.

- Section 6, which gives to eleven languages the status of official languages, is illustrative of the government's commitment to recognise cultural diversities.

- Section 181(1)(c) provides for the establishment of a Commission for the Promotion and Protection of the Right of Cultural, Religious and Linguistic Communities.

- Section 9(3) prohibits unfair discrimination on the grounds of religion, conscience, belief and culture.

- Sections 15, 30 and 31 refer to the rights of traditional, religious, cultural and linguistic communities.

Section 15 of the 1996 Constitution is of particular importance for this study and embodies a combination of at least three freedoms. Firstly, section 15(1) of the 1996 Constitution guarantees freedom of conscience, religion, thought, belief and opinion. The scope of section 15(1) is twofold, namely firstly to demand the freedom to practise one's religion without interference from the state and secondly to demand religious equality. The right to freedom

34 Sections 211 and 212. In terms of section 1 of the Law of Evidence Amendment Act 45 of 1988 judicial notice of customary law by the courts may take place in so far as such law can be ascertained readily and with sufficient clarity. Customs observed within a community may harden into rules of law if it has existed for a long time, has been uniformly observed by the community, is reasonable and is certain. See Van Breda v Jacobs 1921 AD at 330.

35 For a discussion of the functions of the commission and related matters, see Department of Constitutional Development Commission for the Promotion and Protection of the Rights of Cultural, Religious and Linguistic Communities 1 et seq.

36 Mireku 1999 SAPR/PL 447-448. The question may be asked whether section 15 also refers to customary law. It is submitted that section 15(3) does not refer to customary law on the following grounds: (a) customary law issues were a separate debate in the constitutional issues; and (b) customary law is specifically referred to in the 1996 Constitution. See Robinson 1995 SAJHR 468. 
of religion is available to individuals and groups or communities and therefore has an individual and a collective dimension. ${ }^{37}$ Religious freedom is therefore a right that operates both as a liberty right and as an equality right.

In S v Lawrence, S v Negal, S v Solberg the constitutional court had the opportunity to give content to the right to freedom of religion. It had to consider whether certain provisions of the Liquor Act, which prohibit the sale of liquor on Sundays, were unconstitutional in terms of the 1993 Constitution. It was argued on behalf of Solberg that the purpose of the prohibition to sell liquor on Sundays was to "induce submission to a sectarian Christian conception of the proper observance of the Christian Sabbath and Christian holidays or, perhaps, to compel the observance of the Christian Sabbath and Christian holidays". ${ }^{41}$ Such a purpose is inconsistent with the right to freedom of religion and is therefore unconstitutional.

Chaskalson $\mathrm{P}$, who delivered the majority judgement, referred with approval to the definition of freedom of religion in the Canadian case Big M Drug Mart, ${ }^{42}$ where it was stated:

The essence of the concept of freedom of religion is the right to entertain such religious beliefs as a

37 Section 31(1) of the 1996 Constitution lays down that members of a religious community have the right to practise their religion with other members of their community. See also Freedman 2000 Stell LR 107; De Waal, Currie and Erasmus The Bill of Rights Handbook 265. Any religious group, such as Hindus, Muslims and Jews, would be free to practise their religion without fear of interference from the state. Whether such freedom entitles them to have their religious legal systems recognised is another question.

38 Freedom of religion as a liberty right entails "freedom of choice or a space to operate without government interference", and freedom of religion as an equality right entails "freedom from governmental practices which either favour one religion over another and/or religion in general over non-religion". See Freedman 2000 Stell LR 100. Such a viewpoint is supplemented by section 9(2), which guarantees the equal enjoyment of all rights and freedoms, and sections 9(3) and (4) of the 1996 Constitution, which prohibits unfair discrimination on the grounds of religion. De Waal, Currie and Erasmus The Bill of Rights Handbook 263 refers to it as the two components of freedom of religion, namely the free exercise component and the equal treatment component.

391997 (4) SA 1176 (CC). The case dealt with religious freedom, contained in section 14 of the 1993 Constitution. The wording of section 14 is similar to the wording of section 15 of the 1996 Constitution. The principles regarding section 14 would therefore also apply to section 15 of the 1996 Constitution.

4027 of 1989. 41 1206. 42 (1985) 13 CRR 6497. 
person chooses, the right to declare religious beliefs openly and without fear of hindrance or reprisal, and the right to manifest religious belief by worship and practice or by teaching and dissemination.

The definition goes further and requires an absence of coercion or constraint by the state and the absence of measures that could force people to act in a manner contrary to their religious beliefs. ${ }^{43}$ The onus to prove that there has been coercion or constraint that impairs freedom of religion rests with the person alleging such impairment. Chaskalson $\mathrm{P}$ was of the opinion that the right to freedom of religion can only be impaired under two circumstances, namely if there was coercion to observe the practices of a particular religion ${ }^{45}$ or if constraints were placed on the observance of one's own religion by the state. ${ }^{46}$ He held that the relevant provisions ${ }^{47}$ of the Liquor Act did not compel any persons to observe a certain faith. Nor did it in any way "constrain their right to entertain such religious beliefs as they might choose, or to declare their religious beliefs openly, or to manifest their religious beliefs." ${ }^{48}$ As a result the relevant provisions of the Liquor Act that prohibit the sale of liquor on Sundays are not inconsistent with the provisions of the 1993 Constitution. In another case, Garden Cities Incorporated Association Not for Gain $v$ Northpine Islamic Society, ${ }^{50}$ the applicant, who was a developer of townships

431208.

441209.

45 The coercive element of all initiation ceremonies and their roots in ancestor reverence is also a case in point.

461211.

47 Section 90 read with section 159.

48 1209. It is clear that Chaskalson $\mathrm{P}$ prefers the narrow definition of freedom of religion, namely that it is a liberty right. See Freedman 2000 Stell LR 102-108

49 O'Regan $\mathrm{J}$ dissented from the judgement of Chaskalson $\mathrm{P}$ and argued that "the requirements of the Constitution require more of the Legislature than that it refrain from coercion. It requires in addition that the Legislature refrain from favouring one religion over others (1218 par [129])." It is clear that she prefers the wider definition of freedom of religion, namely as a liberty and equality right. See Freedman 2000 Stell LR 103-15, 108110. 5019992 SA 268 (C). The decision was severely criticised by Goolam 1999 THRHR 641643. According to him the decision does not accord with the spirit of the Constitution. He points out that athaan (call to prayer) is a fundamental principle of the Islamic faith which 
in the Cape Peninsula, sold property to the respondent for the purpose of erecting a mosque. In terms of the agreement the respondent would not conduct any activities that would be the source of nuisance or disturbance and the use of sound amplification was prohibited. In spite of these provisions, the respondent had installed sound amplification equipment, and in response to complaints from the residents the applicant approached the court for an order interdicting the respondent to use the sound amplification equipment.

The respondent argued that the call to prayer was one of the basic tenets of Islam and that the clause in the contract prohibiting him from installing sound amplification offended section 15(1) of the 1996 Constitution, which guaranteed religious freedom. In response to the contention of the respondent that he could not waive the call to prayer by refraining from using the sound amplification, the appellant said that the had no objection against calls to prayer by the unassisted human voice. The respondent responded in submitting that it is a basic precept of the Islamic religion that the calls be made as loudly as possible and that the amplification of the human voice was therefore essential. The court did not express a view on the application of the Bill of Rights to the dispute, which was private in nature (so-called horizontal relationship) and assumed in favour of the respondent that the Bill of Rights operates to protect an aggrieved contracting party at the time the contract is sought to be enforced. ${ }^{51}$ The court held that the prohibition against sound amplification did not infringe the right to freedom of religion of Muslims as it merely regulated, by consensus, a particular ritual practised at a particular place in the interests of other members of the community. ${ }^{52}$ The court argued that it would be difficult for parties to a contract to know whether a relinquished right was or was not a fundamental one. The court pointed out that there had been calls to prayer without sound equipment in the past and that there was no evidence that the use of sound equipment was essential to

should not be limited in the light of the 1996 Constitution's guarantee of religious freedom. He concludes by arguing that the tolling of church bells are equally annoying to other members of religious societies and that the striking out thereof would amount to equality of treatment in respect of all noises emanating from religious buildings.

$51270 \mathrm{H}-271 \mathrm{~B}$.

52 271B-C. 
calls to prayers and as a result an order for an interdict prohibiting the use of sound equipment was given. 53

The facts of this case serve as an example of two opposing rights and freedoms in terms of the Bill of Rights. On the one hand, contracting parties should be bound to the provisions of a contract based on the principle of freedom of contract. ${ }^{54}$ On the other hand the parties should not be entitled to exclude fundamental rights by means of contract. In other words, parties should not be able to forego their fundamental rights by means of a contract.

Secondly, section 15(2) regulates state involvement in religious observances conducted at state institutions. These observances may be conducted on an equitable basis and are optional. $^{55}$ In Wittmann v Deutscher Schulverein, Pretoria ${ }^{56}$ the court had to decide, inter alia, whether the freedom of religion clause afforded parents a right to exclude a scholar from attendance at religious instruction classes and observances at school. The court found that section 14(2) of the 1993 Constitution did not apply to the relationship

53 272F-H.

54 Section 9(3) of the 1996 Constitution provides for the full and equal enjoyment of all rights and freedoms and section 39(3) of the 1996 Constitution confirms that other rights (except those especially mentioned in the Bill of Rights) are constitutionally recognised. It is submitted that the principle of freedom of contract is such a freedom that is recognised in terms of the 1996 Constitution.

55 Mireku 1999 SAPR/PL 447. According to Devenish A Commentary on the South African Constitution 57 this provision may be seen as a permissible limitation on the right to freedom of religion. A discussion of section 15(2) falls outside the scope of this study. He points out that section 15(3) in theory allows parents a say in the religious instruction that their children receive in schools. See Devenish 1998 De Jure 232.

5619984 SA $423(\mathrm{~T})$. The court decided to apply the 1993 Constitution to the facts of the case. However, the decision of the court regarding freedom of religion is also relevant with regard to the 1996 Constitution.

57 The court argued that religious observance is an act of religious character, for example, the daily opening of a school by prayer whilst religious education is not. Even if religious instruction were a religious observance, the 1993 Constitution granted the rights to conduct religious observances at state and state-aided institutions and that right could not be nullified by those who had the right to abstain from them but chose not to. The religious instruction classes at the school were therefore not unconstitutional. However, the right to freedom of religion, thought, belief and opinion entailed that attendance of the religious instruction classes be voluntary (449-450). Also of interest, and then from a cultural perspective, is that the parents acted on behalf of their child and its religious (and broadly cultural) affiliation. The assumption is that the child ipso facto "belongs" to the same religious and cultural community as the parents. 
between the parent and the school, as the latter is not a state aided institution or an organ of state. 58

Thirdly, section $15(3)$ deals with legislative recognition of systems of personal or family law based on religion or culture and states:

(a) This section does not prevent legislation recognising-

(i) marriages concluded under any tradition, or a system of religious, personal or family law; or

(ii) systems of personal and family law under any tradition, or adhered to by persons professing a particular religion.

(b) Recognition in terms of paragraph (a) must be consistent with this section and the other provisions of the Constitution.

Section 15(3)(a) paves the way for the future recognition of religious and cultural legal systems, such as Hindu law, Islamic law and Jewish law or marriages concluded in terms of these religions. ${ }^{60}$ The scope and meaning of this provision is of particular importance. The first question that arises is whether section 15(3)(a) creates a right to have one's system of personal or family law recognised. In other words, does section 15(3)(a) recognise a right

58 According to the court the fact that the school received state funding did not mean that the state was in control of the school. The fact that the state determined the age of the pupils, educational standards, qualifications of teachers, hours of schooling and school calendar, including the approval of the school's constitution and annual financial statements by the state, had no effect on the fact that the school is not a state aided institution.

59 See Freedman 1996 HRCLJSA 36.

60 According to Smith 1997 SALJ 222 section 15(3) exempts the type of legislation under discussion from challenges in terms of section 15. He points out that nothing in sections 15(1) of 15(2) may be understood to prohibit religious or customary family law. 
to have Hindu personal law, Jewish personal law or Muslim personal law recognised. Read with the right to freedom of association ${ }^{61}$ and the right of religious and traditional communities, 62 one may argue that freedom of religion and other culturally based rights includes the right to have the personal laws of those religious and traditional communities recognised. ${ }^{63}$ This is particularly so if one takes into consideration the argument that those religious and traditional legal systems generally do not distinguish between law and religion or between law and tradition. It is argued that concepts or principles of law and religion or tradition are so intermingled that interference with the one would lead to interference with the other.

It seems, however, that the overwhelming opinion is in favour of the argument that section 15(3)(a) does not recognise a right to have religious and traditional legal systems recognised. ${ }^{65}$ It is submitted that the right to freedom of religion and other culturally based rights does not create a right to have a legal system based on religion or tradition recognised in terms of section 15(3)(a). In other words, section 15(3)(a) only warrants recognition of religious and traditional legal systems by means of legislation and does not create a right to have those legal systems recognised.

The second question deals with the apparent conflict between the right to freedom of religion and culture and other provisions of the Bill of Rights. For example, polygyny, which is allowed in terms of Hindu law and Islamic law,

61 Section 18. According to Devenish A Commentary on the South African Bill of Rights 418 the right to freedom of association protects the freedom of every person to associate with others according to his or her free choice. The inclusion of a separate right to culture in terms of sections 30 and 31 was therefore unnecessary.

62 Section 31.

63 According to Mireku 1999 SAPR/PL 447 section 15(3)() gives official recognition to marriages concluded under any tradition, or a system of religious, personal or family law. He is of the opinion that the courts may thus give effect to the consequences of any valid marriage solemnised under customary, civil or Islamic law. It is submitted that his argument is not correct. Section 15(3) does not recognise the validity of marriages concluded under any tradition or religion. It only provides for legislation recognising such marriages subject to the provisions of the 1996 Constitution.

64 There are also arguments to the contrary. 65 Moosa An Analysis of the Human Rights and Gender Consequences of the New South African Constitution and Bill of Rights 354. 
prima facie discriminates against women. Also, in terms of the Hindu law, Islamic law and Jewish law the position of a woman with respect to inheritance is generally unequal to that of her male counterpart. Section $15(3)(b)$ clearly states that recognition in terms of section 15(3)(a) must be consistent with the provisions of the 1996 Constitution. Read with section 31(2), which provides that the right of a religious group to practise their religion or a cultural group to enjoy their culture must be consistent with the provisions of the Bill of Rights, it is clear that other rights might trample the right to freedom of religion or culture. For example in Christian Education SA $v$ Minister of Education of the Government of the $R_{S A}{ }^{67}$ the court held that corporal punishment, which was the religious belief of the appellant, violated the right to human dignity ${ }^{68}$ and right to security of the person.

According to Freedman ${ }^{70}$

No state can, for example, permit practices such as enforced polygamy, ritual murders, or public disturbances simply because they are mandated by religious beliefs. The state must be able to limit those practices, whether religious or not, which endanger the life and health of others or which limit the rights of others or which create public disturbances or undermine public morals.

He acknowledges that it would not be easy to strike a balance between religious liberty and the state's duty to legislate for the common good. This is exactly the difficulty the South African legislature is going to face. On the one hand, vociferous members of religious and traditional communities are going

66 De Waal, Currie and Erasmus The Bill of Rights Handbook 277. In Kalla v The Master 19951 SA 261 (T) $270 \mathrm{G}-\mathrm{H}$ the court remarked that the principle of gender equality could lead to the conclusion that polygamous and potentially polygamous unions "are as unacceptable to the mores of the new South Africa as they were to the old." For a discussion of the facts of the case, see Bonthuys and Du Plessis 1995 SAPR/PL 200-210.

6719999 BCLR 951 (SE). 68 Section 10. 69 Which included the right to be protected against punishment that is cruel, inhuman or degrading (section 12(1)(e)). 
to demand full and unchanged recognition of their religion or tradition, which includes the legal rules of such a religion, and on the other hand, the state has the duty to ensure constitutional protection of the rights of the adherents to those religions or traditions. The drafting of legislation that recognises religious and traditional legal systems other than the systems already in operation in South Africa will not be an easy task. If all the discriminatory elements are not removed by means of legislation the recognition will not be in compliance with section 15(3)(b).

On the other hand, if all the discriminatory elements are removed by means of legislation the recognition might not be acceptable to the visible proponents of the relevant religious and traditional communities and will result in the legislation becoming mere paper law. However, these difficulties should not prevent the legislature and courts from abolishing unfair discrimination (based on sex and gender) and unacceptable coercion of individuals within religious and traditional legal systems.

Freedom of religion, belief and opinion protected in section 15(1) must be distinguished from the culturally and religiously based rights protected in terms of sections $30^{71}$ and $31^{72}$ of the 1996 Constitution. Section 31 must be read with section 235, which deals with the self-determination of a cultural community "sharing a common cultural and language heritage." ${ }^{73}$ Some

701996 THRHR 668.

71 Section 30 reads: "Everyone has the right to use the language and to participate in the cultural life of their choice, but no one exercising these rights may do so in a manner inconsistent with any provision of the Bill of Rights."

72 Section 31 reads: "(1) Persons belonging to a cultural, religious or linguistic community may not be denied the right, with other members of that community- (a) to enjoy their culture, practice their religion and use their language; and (b) to form, join and maintain cultural, religious and linguistic associations and other organs of civil society. (2) The rights in subsection (1) may not be exercised in a manner inconsistent with any provision of the Bill of Rights."

73 Such self-determination must be determined by national legislation. Section 235 of the 1996 Constitution reads: "The right of the South African people as a whole to self-determination, as manifested in this Constitution, does not preclude, within the framework of this right, recognition of the notion of the right of self-determination of any community sharing a common cultural and language heritage, within a territorial entity in the Republic or in any other way, determined by national legislation." See Strydom 2000 TSAR 346-359. This approach is very much the result of the poltical negotiations leading up to 1994, and although it may be an important mechanism for accommodating diverse political forces, it also assumes that a cultural category is a homogeneous unit with clear boundaries. 
writers argue that section 31 guarantees a collective right, whilst sections 9, 15 and 30 guarantee individual rights to religion and culture. Both sections 30 and 31 restrict the exercising of cultural and religious-based rights subject to the provisions of the Bill of Rights.

Another right that closely relates to cultural and religious-based rights, is freedom of association. In terms of section 18 of the 1996 Constitution "everyone has the right to freedom of association." ${ }^{75}$ Section 18 warrants the subsistence of, inter alia, cultural and religious associations. Considering the political history of South Africa it is doubtful whether section 18 could be used to sanction "private apartheid" under the pretext of freedom of association. 76

\section{$3 \quad$ Concluding remarks}

A "multicultural" society like South Africa is liable to pose an enormous challenge to the implementation of a Bill of Rights. On the one hand the state has the responsibility to ensure vis-à-vis the 1996 Constitution that the values enshrined in the Bill of Rights are enforced and applied to all citizens. These values include human dignity and equality and prohibit unfair discrimination on the grounds of gender and sex. On the other hand the seemingly discriminating religious and traditional laws are based upon values, which from the viewpoint of vocal and organised activists "representing" cultural and religious groups, are not subject to censure on any ground whatsoever.

The fact that culturally and especially religiously determined values are regarded by these "representatives" of traditional communities as sacred, unbeatable and not subject to censure, appears to be an extremely complicating factor in reconciling constitutional values with "traditional values".

74 Mireku 1999 SAPR/PL 450; Devenish A Commentary on the South African Bill of Rights 421. According to Currie Minority Rights 35.13-35.14 section 31 protects both individual and group interests in culture and religion. In the first place it protects the right of the group to enjoy their culture and religion, and in the second place it protects the right of the individual to participate in the cultural or religious group of his or her choice.

75 For a detailed discussion of section 18 see Devenish A Commentary on the South African Constitution 61; Woolman Freedom of Association 22.1-22.12; De Waal, Currie and Erasmus The Bill of Rights Handbook 312-318.

76 Devenish A Commentary on the South African Constitution 61. 
It may be difficult, if not impossible, to provide a workable and final solution to this complex problem. Regard should be taken of the fact that the 1996 Constitution was introduced a mere six years ago and any attempt to come forward with a viable final solution may well be tainted with over-simplification. It is still early days and in view of the complex and extensive nature of the problem, an evolutionary process towards a dispensation where the conflicting values are judicially reconciled is required.

There are, as it were, two opposing centric forces that may well be irreconcilable within the context of the 1996 Constitution as such. These conflicting interests have the potential of causing a constitutional tug-of-war between the selfsame constitutional values provided for in the 1996 Constitution, namely the right to equality on the one hand and to cultural and religious based rights on the other hand.

As South Africans, we come from a background that starkly indicates how dangerous it can be to categorise people into groups based on certain characteristics, for example a person's race. In the previous political dispensation the assumption was that the diversity within South Africa is static and part of a natural order. Therefore, we should warn against these old ways of thinking, as even reflected in the use of the concept culture in the 1996 Constitution. Because cultural resources are shared, it also does not mean that activists appearing before the constitutional court and making an appeal on cultural or religious values and traditions speak on behalf of more than themselves. Because of the complexity of life, they are definitely not appealing on behalf of "all the members of X-culture". We have experienced the sensitivity of constitutional court judges regarding the complexity of South African life and we trust that an oversimplified, static approach, which does not allow for a diversity of experience and interest within cultural categories (as most activists would prefer it), will not influence their thinking. Visible and vocal "representatives" of "culture $X$ " should therefore be recognised as coming from specific class-based, gender-based, occupation-based, regional, and generational backgrounds with specific perspectives of what the cultural and religious values and practices of "culture X" is or should ideally be. 
Hopefully these arguments will provide some background before we embark on extensive spadework with a view to pave the way for understanding culture and religion in constitutional adjudication. 